Review paper

\title{
Quercus cerris L.: An Overview
}

\section{Rola Najib ${ }^{1 *}$, Tarek Houri ${ }^{2}$, Yara Khairallah ${ }^{3}$ and Mahmoud Khalil $^{1}$}

\begin{abstract}
Najib, R., Houri, T., Khairallah, Y., Khalil, M. 2021. Quercus cerris L.: An Overview. - Forestry Studies | Metsanduslikud Uurimused 74, 1-9, ISSN 1406-9954. Journal homepage: http:/ / mi.emu.ee/forestry.studies
\end{abstract}

\begin{abstract}
The Turkey oak is a frequent tree species in the Mediterranean climate zones of southern Europe and Asia Minor. It has been used in the human diet, for medicinal purposes, firewood and charcoal production. Like all oaks, Turkey oak is suffering from dieback and decline owing to the combination of several detrimental factors, such as insects, diseases and unfavorable environment, leading to their deterioration and sometimes resulting in their early death.
\end{abstract}

Key words: Quercus cerris L., distribution, microorganisms, pests, diseases, pollution.

Authors' addresses: ${ }^{1}$ Beirut Arab University, Faculty of Science, Department of Biological Sciences, Debbieh Campus, P.O.Box 11-5020 Beirut, Lebanon; ${ }^{2}$ Beirut Arab University, Faculty of Science, Department of Biological Sciences, Tripoli Campus, P.O.Box 11-5020 Beirut, Lebanon; ${ }^{3}$ Lebanese Agricultural Research Institute, Department of Soil, Plants and Fertilizers, Fanar, Main Road, 90-1965, Jdeidet El-Metin Fanar, Lebanon; *e-mail: ryn473@student.bau.edu.lb

\section{Distribution of Quercus cerris L. and Physical Characteristics}

The genus Quercus, commonly known as oak, is considered as one of the most dominant group of woody angiosperms in the northern hemisphere and is well evaluated for its economic importance and species diversity (Tantray et al., 2017). Turkey oak is a member of this genus and naturally grows in southern Europe and Asia Minor (de Rigo et al., 2016). Across its distribution range, it is notably found in England, France, Italy, the Balkan Peninsula, as well as Albania (Stafasani \& Toromani, 2015). Turkey oak is also found in Lebanon where it constitutes $14 \%$ of broadleaved trees species (Figure 1). Table 1 represents the international common names of Quercus cerris.
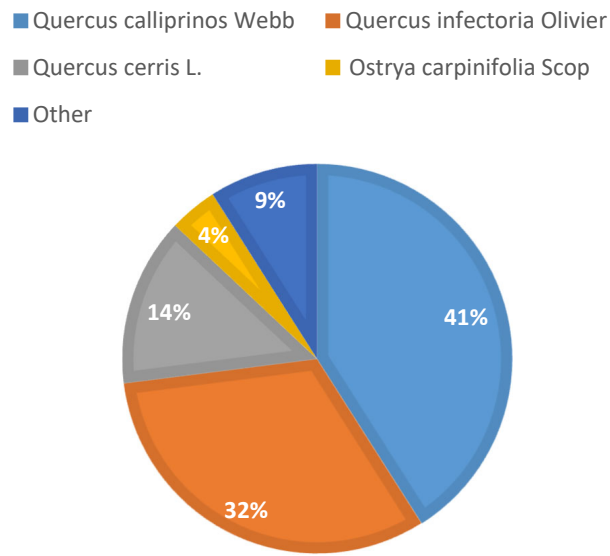

Figure 1. Relative frequency of broadleaved tree species in Lebanon. 
Table 1. International common names of Quercus cerris L.

\begin{tabular}{|c|c|c|}
\hline Language & Name & References \\
\hline English & $\begin{array}{l}\text { Turkey oak, Austrian } \\
\text { oak, Bitter oak, Iron } \\
\text { oak, Mossy-cupped oak }\end{array}$ & $\begin{array}{l}\text { CABI, } 2021 \\
\text { Burlacu et } \\
\text { al., } 2020\end{array}$ \\
\hline French & $\begin{array}{l}\text { Chêne chevelu, chêne } \\
\text { de Bourgogne, Chêne } \\
\text { de Turkuie, Cerre }\end{array}$ & CABI, 2021 \\
\hline Arabic & Ezer & $\begin{array}{l}\text { Lebanon } \\
\text { Flora, } 2013\end{array}$ \\
\hline Spanish & Marojo & CABI, 2021 \\
\hline Italian & Cerro, Serro & CABI, 2021 \\
\hline
\end{tabular}

Turkey oak is a long-lived deciduous tree which loses its leaves at the end of its growing season. It can reach the height of 30-40 meters under favorable conditions with a trunk of up to 2 meters in diameter (de Rigo et al., 2016). It has a thick, dull grey, deeply fissured bark (Figure 2) (Gilman \& Watson, 1994). The grey twigs are gnarled and slightly pubescent with lenticels. The buds are ovoid, with long hairy stipules, and persistent twisted scales. The thick and rough dark green leaves of Turkey oak consist of 5 to 9 deep lobes and are generally between 9 and $12 \mathrm{~cm}$ in length and 3-5 $\mathrm{cm}$ in width (Figure 3). During autumn, the leaves eventually turn yellow and fall.

Turkey oak is a monoecious tree that bears both unisexual flowers and is typically wind pollinated in spring. The species produces widely known fruit, commonly identified as acorns that are approximately $3 \mathrm{~cm}$ long (Figure 4) and mature 18 months after pollination. It should be noted that the acorns are surrounded at the base by a hairy cup known as the cupule that holds and protects the fruit during its growth and maturation.

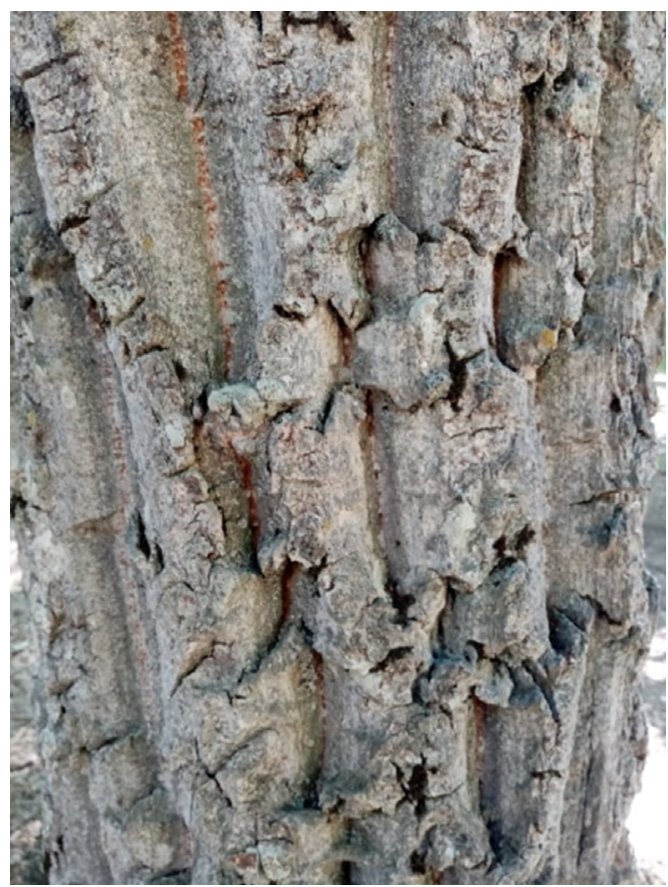

Figure 2. The bark shape of Turkey oak.

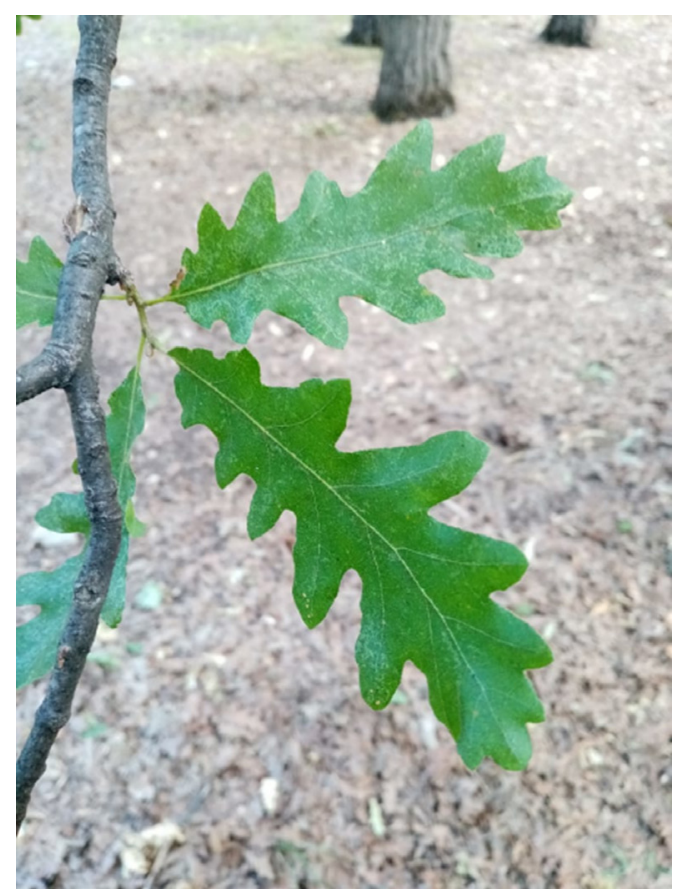

Figure 3. The dark green leaves of Turkey oak. 


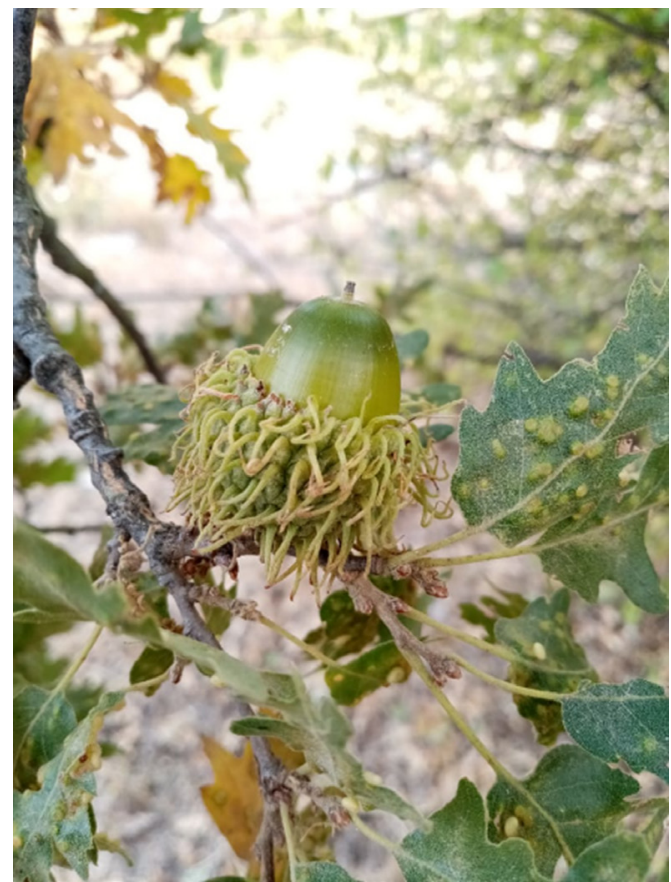

Figure 4. Acorns with a hairy cup.

\section{Habitat and Ecology}

Quercus cerris is considered as a Mediterranean oak tree which thrives under Mediterranean climatic conditions (Figure 5) (Bozzano \& Turok, 2003; Di Iorio et al., 2007). It is a hardy, fast-growing plant, relatively tolerant to frost, drought and salt, and can grow in most soil types, including clay, heavy clay, loam, acid, neutral, and alkaline soils (Gilman \& Watson, 1994). Well-drained soil and full sun are best for its optimal growth and flowering. However, studies have pointed out that Turkey oak can survive in and adapt well to intense canopy conditions (Bobinac et al., 2019).

In addition, Quercus cerris is considered as a pollution-tolerant tree (de Rigo et al., 2016). Indeed, air pollution presents a global problem which does not only affect animals and humans but has many harmful impacts on plants, as well. Some of these effects are visible especially in leaf colors, shapes, width and petiole length.

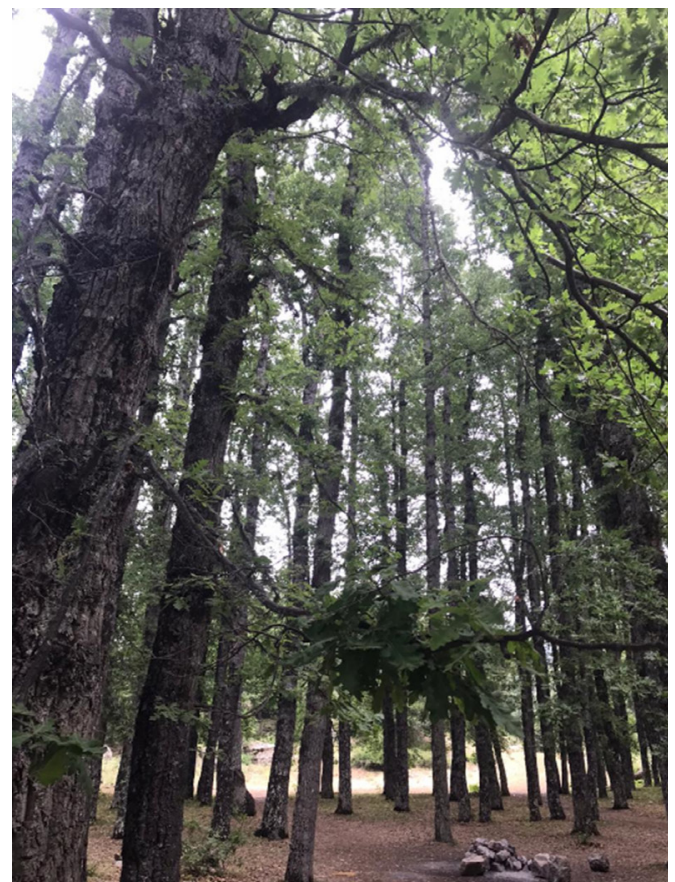

Figure 5. Forest dominated by Turkey oak in North Lebanon.

While others are invisible like stomatal closure, decrease in transpiration rate and inhibition of photosynthetic activity (Rai, 2016; Saxena \& Kulshrestha, 2016).

The responses of trees to pollution stresses vary widely among species. Some species are considered as sensitive while others are reported as tolerant plants accumulating pollutants in their bodies (Rai, 2016).

Tzvetkova and Kolarov (1996) showed in their study on four different tree species that Quercus cerris, growing in a region with significant industrial emissions, was the most tolerant to air pollution. In their study, it was observed that Quercus cerris leaves collected from polluted sites have accumulated large amounts of toxic elements, but simultaneously showed minor variations of carbohydrate concentration which demonstrated good tolerance and resistance of the species to air pollution and reinforced the idea of using it for afforestation of industrial areas. 


\section{Value of Quercus cerris}

Turkey oaks are multifunctional trees enabling a wide range of goods and services. They offer not only environmental protection but also revenue and livelihood options for forest-dependent communities.

They are well known by their ability to grow in a broad range of soil conditions, making them useful in soil cover, reforestation and erosion prevention (Mert et al., 2016).

Compared to other oaks, Turkey oak wood is less valued because of its susceptibility to split and its lower resistance and durability (Ferrari et al., 2013). It is primarily used to make charcoal, for temporary constructions and firewood. Nowadays, Turkey oak wood is used for manufacturing wine barrels in Albania, because they impart flavor and color to the wine inside (Stafasani et al., 2018).

The seeds of Turkey oak can have several uses. They can be dried, grounded into powder and used as thickening agents or mixed with cereals for making bread. Roasted seeds are used in the preparation of a coffee-like beverage (Pinto et al., 2019).

Additionally, a sweet fluid (saccharine fluid) exudes from insect damage on the stems and solidifies. This saccharine secretion is edible and is sold in local markets in Kurdistan and Iran. In fact, this fluid is boiled down into a syrup and used in sweetening food or mixed with flour for making a cake (Hedrick, 1919).

Furthermore, Turkey oak acorns represent an important source of food for some wildlife. These fruits have been also described as containing high contents of tannins and therefore are strongly astringent (Vinha et al., 2016).

Studies revealed that galls, barks and leaves are all rich in active compounds with antioxidant activity, such as tannins, and are therefore used in traditional medicine for numerous purposes, including the treatment of hemorrhages, dysentery, chronic diarrhea, and gum problems (Taib et al., 2020).

Moreover, scientific reports have validated the use of Quercus cerris extracts against some pathogenic microorganisms. In fact, antimicrobial resistance is one of the serious problems the world is facing today since resistant pathogens develop resistance to drugs currently used for infectious diseases. In addition, many synthetic antimicrobial agents have side effects on human patients, including hypersensitivity and allergic reactions (Şöhretoğlu et al., 2007; Smailagić et al., 2020). For these reasons, the discovery of alternative drugs derived from natural resources is needed.

According to research, organic extracts of Quercus cerris acorns have antioxidant and antimicrobial properties, which could be explained by their richness in bioactive phenolic compounds, such as tannins and flavonoids (Vinha et al., 2016).

Research showed also that the butanol extracts of Quercus cerris leaves exhibit antibacterial activity against Staphylococcus aureus and display good antifungal activity, especially against Candida krusei (Şöhretoğlu et al., 2007; Hobby et al., 2012). In addition, Smailagić et al. (2020) reported in their study that extracts of Quercus cerris wood could be used against the Methicillin-resistant Staphylococcus aureus (MRSA). The antimicrobial activity of these extracts could be attributed to their phenolic acid contents, including gallic and ellagic acid. Table 2 represents the minimum inhibitory concentration (MIC) of various Quercus cerris extracts on different pathogens.

\section{Pests and Diseases}

Similar to other oak species, the Turkey oak has suffered periods of decline, attributed to a variety of interacting biotic and abiotic causes (Amorini et al., 1996; Gottschalk \& Wargo, 1997; Colangelo et al., 2018). It is usually attacked by the prevalent diseases of oaks which include oak mildew, oak wilt, chestnut blight, anthracnose, oak leaf 
Table 2. Summarized MIC values for different Quercus cerris extracts obtained from literature data.

\begin{tabular}{lccccccccl}
\hline $\begin{array}{l}\text { Quercus cerris extracts MIC } \\
(\mu \mathrm{g} / \mathrm{mL})\end{array}$ & $S m$ & $S a$ & $S p$ & MRSA & $L m$ & $C a$ & $C k$ & $C p$ & References \\
\hline Leaf butanol extract & - & 200 & - & - & - & 64 & 64 & 128 & $\begin{array}{l}\text { Hobby etal., 2012 } \\
\text { Şöhretoğlu et al., 2007 }\end{array}$ \\
Leaf ethyl acetate extract & - & - & - & - & - & 128 & 64 & 128 & Şöhretoğlu et al., 2007 \\
Leaf aqueous extract & - & - & - & - & - & 128 & 64 & 128 & Şöhretoğlu et al., 2007 \\
Stem/root butanol extract & - & 200 & - & - & - & - & - & - & Hobby et al., 2012 \\
Wood methanol extract & 130 & 30 & 80 & 30 & 500 & - & - & - & Smailagić et al., 2020 \\
\hline
\end{tabular}

Sm: Streptococcus mutans; Sa: Staphylococcus aureus; Sp: Streptococcus pyogenes; MRSA: Methicillin-resistant Staphylococcus aureus; Lm: Listeria monocytogenes; Ca: Candida albicans; Ck: Candida krusei; Cp: Candida parapsilosis; (-): not tested.

blister, and leaf spots (Ragazzi et al., 2007; Marçais \& Desprez-Loustau, 2014).

Powdery mildew of oak is a disease caused by different species of fungi which attack young leaves. It starts as little white spores usually on the lower leaves of the tree and then spread over the entire tree if left untreated. The spores cover the leaves and inhibit photosynthesis causing them to wilt and fall off. Early detection provides the best way to contain the spread of this disease. In most situations, fungicides are sprayed to prevent the fungi from stunting the growth of seedlings and young trees (Lonsdale, 2016; Lamp'1, 2021). The use of fungicides, although being strongly effective, might be impracticable in a forest situation where there is a large number of trees, or may be illegal in some countries (Lonsdale, 2016). Thus the use of an alternative treatment method is needed. One of the possibilities that could be investigated is the use of natural control agents, such as pathogens that can parasitize the oak powdery mildew fungi and eventually inhibit the formation of its spores.

Oak wilt is caused by Ceratocystis fagacearum which blocks the movement of water and nutrients in the xylem, causing the death of trees. Once an infection is established, the oak wilt fungus moves swiftly from the infected tree to adjoining ones through root grafts that exist between them. To contain the problem, trenches should be dug to a depth of at least three feet between diseased and healthy oaks to minimize the root graft transmission of the fungus (Figure 6). Trenches should be installed approximately 100 feet from the infected tree that should be afterwards removed. Symptom-free oaks grown within the trench line should be protected by injecting trunks with a systemic fungicide to eliminate the possibility of disease spread (Wilson, 2005; Fite, 2018).

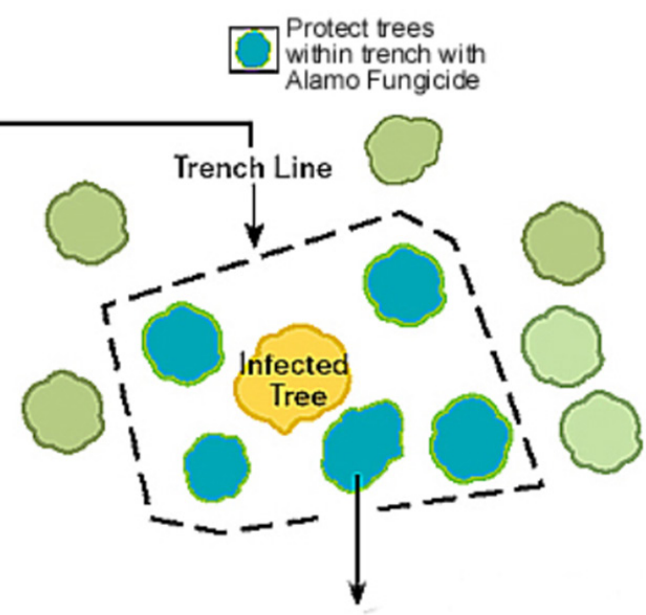

Figure 6. Trenches installed around the infected tree (Adopted from Fite, 2018).

Chestnut blight is actually a canker disease caused by a fungus, Cryphonectria parasitica. It attacks and damages the outer bark layer of oak trees but usually cannot affect the roots, because other microorganisms in soil impede the growth of the blight 
fungus and eventually kill it. Researchers take advantages of this phenomenon and cure the diseased tree by packing soil over trunk cankers. This practice for combating blight canker is known as the soil compress method. The basics of this biological method are simple. It consists of taking soil from around the base of an infected tree and mixing it with water to cause it to become watery. A plastic sleeve is then wrapped around an existing canker with waterproof tape. After that, the plastic material should be filled at least two inches thick with the wet soil and secured at the top with tape or string to prevent the soil compress from drying. The compress should be extended at least one foot above and below the cankered area and retained in place for at least a couple of months (Figure 7) (Weidlich, 1978).

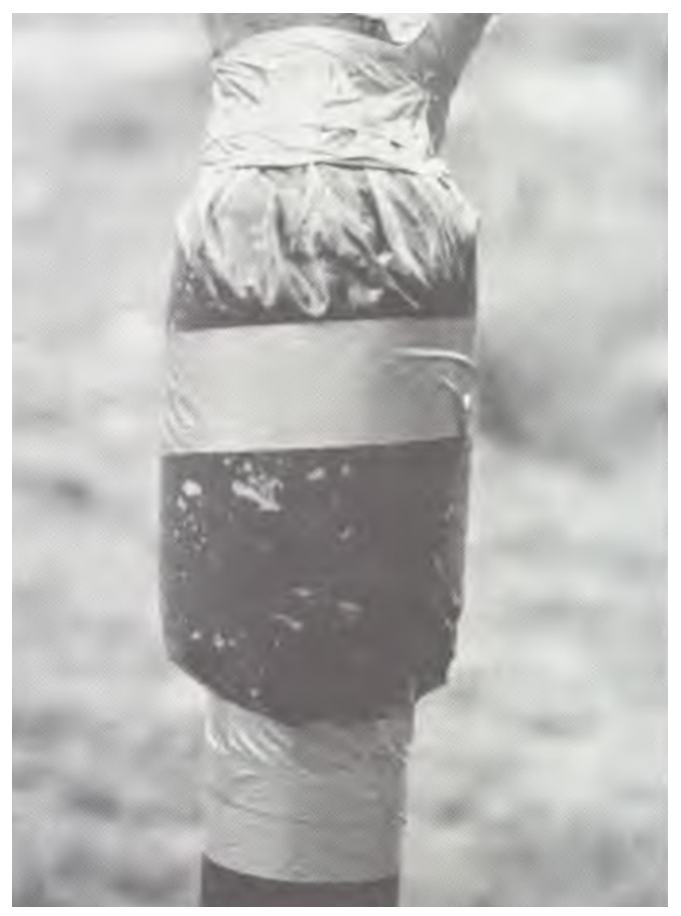

Figure 7. Soil compress plastered all over the canker (Adopted from Weidlich, 1978).

The soil compress method has been applied in Albania by a group of researchers to heal infected chestnut tree barks me- chanically (Ndreu \& Shehi, 2021). Briefly after cleaning the cankered area with a sickle, the muddy soil was plastered all over the cankerous wound and kept till the end of the growing season. Soil was collected from under the diseased tree and mixed with water and copper sulphate. The latter is an inorganic compound generally used to kill fungi and bacteria. This method differs from other traditional methods by cleaning the part affected by blight canker and then plastering the gooey mud. Tree cleaning allows the wood to start the recovery process of the cankerous wound and inhibits the spread of canker to other trees. The implementation of this method has enabled improvement of the condition of infected chestnut plantations, minimized their drying and enhanced their productivity. Therefore, application of this simple method to treat other infected trees, such as oaks, could be interesting.

A chemical method can also be applied to control chestnut blight disease. This method consists of spraying fungicides, such as copper oxychloride, copper sulphate and thiophanate methyl on the wound.

Anthracnose disease is caused by many different fungi that create irregular-shaped brown lesions on leaves. As the disease gets worse, the tree branches can also become infected with the anthracnose fungus and start to crack. The management of anthracnose consists of pruning out the diseased branches and removing infected leaves and twigs. Trees may also be injected with systemic fungicides. Some applied fungicides can trigger the tree's natural defense mechanisms rendering it more tolerant to infection with faster recovery time; whereas others can directly kill the fungus itself and are recommended when the infection is particularly severe and recurs every year (Arborjet, 2020).

As for oak leaf blister, it is caused by the Taphrina caerulescens fungus. Cool wet weather favors this pathogen which produces brown blotches preceded by light 
green blisters on the upper leaf surface. In severe infestation cases the tree may drop all of its leaves. In addition, Turkey oak is susceptible to Discula quercina, Phomopsis quercina and Hypoxylon mediterraneum fungi (Vannini et al., 1996; Ragazzi, 2001; Moricca \& Raggzi, 2008). It can also be infected by pathogens such as the Phytophthora species, including $P$. cinnamomi, which flourish in winter climate conditions (Oh et al., 2011).

Turkey oak is also attacked by a wide range of pests that cause damage to the tree, including scale, oak skeletonizer, leaf miner, oak lace bugs, borers, caterpillars, and nut weevils.

\section{Conclusion}

Turkey oak, growing in most soil types, is one of the most important resources providing multiple benefits to people. It is used in foods, traditional or folk healing practices and has showed antimicrobial properties against some human pathogenic microorganisms. However, further studies are needed to assess the antioxidant and antimicrobial activities of different tree parts against a broader range of pathogens in order to encourage its use in pharmaceutical industries. Furthermore, to fight environmental pollution that affects ecosystems in a number of ways, and since Turkey oak is considered as a pollution-tolerant tree species, it could be highly recommended for afforestation along roadsides and in industrial regions.

Acknowledgements. We are thankful to all the authors who contributed to the original research articles.

\section{References}

Amorini, E., Biocca, M., Manetti, M.C., Motta, E. 1996. A dendroecological study in a declining oak coppice stand. - Annales des Sciences Forestières, 53(2-3), 731-742.

Arborjet. 2020. Anthracnose. [WWW document]. - URL https://arborjet.com/problems_ solutions/anthracnose/. [Accessed 9 February 2021].

Bobinac, M., Andrašev, S., Šušić, N., BauerŽivković, A., Kabiljo, M. 2019. Growth characteristics of three-year-old Turkey oak (Quercus cerris L.) seedlings from natural regeneration under a dense canopy stand. Biologica Nyssana, 10(2), 105-111.

Bozzano, M., Turok, J. 2003. Mediterranean Oaks Network. - Report of the second meeting of the Mediterranean Oaks Network, Malta, May 2002. Gozo, 28-31.

Burlacu, E., Nisca, A., Tanase, C. 2020. A comprehensive review of phytochemistry and biological activities of Quercus species. Forests, 11(9), 904. https://doi.org/10.3390/ f11090904.

CABI. 2021. Quercus cerris (European Turkey oak). [WWW document]. - URL https://wwW. cabi.org/isc/datasheet/46407. [Accessed 31 January 2021].

Colangelo, M., Camarero, J.J., Borghetti, M. Gentilesca, T., Oliva, J., Redondo, M.A., Ripullone, F. 2018. Drought and Phytophthora are associated with the decline of oak species in southern Italy. - Frontiers in Plant Science, 9, 1595. https://doi.org/10.3389/ fpls.2018.01595.

de Rigo, D., Enescu, C.M., Houston Durrant, T., Caudullo, G. 2016. Quercus cerris in Europe: distribution, habitat, usage and threats. - SanMiguel-Ayanz, J., de Rigo, D., Caudullo, G., Houston Durrant, T., Mauri, A. (eds.). European Atlas of Forest Tree Species. Luxembourg, Publications Office of the European Union, 148-149.

Di Iorio, A., Lasserre, B., Scippa, G.S., Chiatante, D. 2007. Pattern of secondary thickening in a Quercus cerris root system. - Tree physiology, 27(3), 407-412. https://doi.org/10.1093/ treephys/27.3.407

Ferrari, S., Allegretti, O., Cuccui, I., Moretti, N., Marra, M., Todaro, L. 2013. A revaluation of Turkey oak wood (Quercus cerris L.) through combined steaming and thermo-vacuum treatments. - BioResources, 8(4), 5051-5066.

Fite, K. 2018. Managing oak wilt disease. - Research Laboratory Technical Report, The Bartlett Tree Research Laboratories. 3pp.

Gilman, E.F., Watson, D.G. 1994. Quercus cerris -Turkey oak. - Fact Sheet ST-544. Gainesville, FL, University of Florida. 3 pp. 
Gottschalk, K.W., Wargo, P.M. 1997. Oak decline around the world. - Fosbroke, S.L.C., Gottschalk, K.W. (eds.). Proceedings of the U.S. Department of Agriculture Interagency Gypsy Moth Research Forum, United States, Jan. 1996. Annapolis, 3-13.

Hedrick, U.P. 1919. Sturtevant's Edible Plants of the World. Geneva, New York, New York Agricultural Experiment Station. 545.

Hobby, G.H., Quave, C.L., Nelson, K., Compadre, C.M., Beenken, K.E., Smeltzer, M.S. 2012. Quercus cerris extracts limit Staphylococcus aureus biofilm formation. - Journal of Ethnopharmacology, 144(3), 812-815. https:/ / doi.org/10.1016/j.jep.2012.10.042.

Lamp'l, J. 2021. Controlling or eliminating powdery mildew. [WWW document]. - URL https://www.growingagreenerworld.com/ controlling-or-eliminating-powdery-mildew/. [Accessed 2 February 2021].

Lebanon Flora. 2013. Quercus cerris L. [WWW document]. - URL http:/ / www.lebanon-flora. org/species.php?id_pl=352\&bp =fam\&bp fam $=$ Fagaceae\&bp_gen=Quercus. $\quad$ [Accessed 31 January 2021].

Lonsdale, D. 2016. Powdery mildew of oak: a familiar sight with some hidden surprises. [WWW document]. - URL https://www. ancienttreeforum.co.uk/wp-content/ uploads / 2016/02/ Arb-mag-Spring-2016powdery-mildew-of-oak.pdf. [Accessed 2 February 2021].

Marçais, B., Desprez-Loustau, M.L. 2014. European oak powdery mildew: impact on trees, effects of environmental factors, and potential effects of climate change. - Annals of Forest Science, 71(6), 633-642. https://doi.org/10.1007/ s13595-012-0252-x.

Mert, A., Özkan, K., Şentürk, Ö, Negiz, M.G. 2016. Changing the potential distribution of Turkey oak (Quercus cerris L.) under climate change in Turkey. - Polish Journal of Environmental Studies, 25(4), 1633-1638. https://doi. org/10.15244/pjoes/62230.

Moricca, S., Raggazi, A. 2008. Fungal endophytes in Mediterranean oak forests: a lesson from Discula quercina. - Phytopathology, 98(4), 380-386. https://doi.org/10.1094/ PHYTO-98-4-0380.

Ndreu, R., Shehi, M. 2021. New ways of combating chestnut blight canker. [WWW document]. - URL https://www.yumpu.com/en/ document/view / 28702412/new-ways-ofcombating-chestnut-blight-canker. [Accessed 5 February 2021].

Oh, E., Wingfield, B.D., Wingfield, M.J., Roux, J. 2011. First report of Phytophthora cinnamomi associated with stem cankers of Quercus cerris in South Africa. - New Disease Reports, 24, 11. http://dx.doi.org/10.5197 /j.2044-0588.2011.024.011.
Pinto, D., Franco, S.D., Silva, A.M., Cupara, S., Koskovac, M., Kojicic, K., Soares, S., Rodrigues, F., Sut, S., Dall'Acqua, S., Oliveira, M.B.P.P. 2019. Chemical characterization and bioactive properties of a coffee-like beverage prepared from Quercus cerris kernels. - Food \& Function, 10, 2050-2060. https://doi.org/10.1039/ C8FO02536C.

Ragazzi, A., Moricca, S., Capretti, P., Dellavalle, I., Mancini, F., Turco, E. 2001. Endophytic fungi in Quercus cerris: isolation frequency in relation to phenological phase, tree health and the organ affected. - Phytopathologia Mediterranea, 40(2), 165-171.

Ragazzi, A., Turco, E., Marianelli, L., Dellavalle, I., Moricca, S. 2007. Disease gradient of the anthracnose agent Apiognomonia quercina in a natural oak stand. - Phytopathologia Mediterranea, 46(3), 295-303.

Rai, P.K. 2016. Impacts of particulate matter pollution on plants: Implications for environmental biomonitoring. - Ecotoxicology and Environmental Safety, 129, 120-136. https://doi.org/10.1016/j.ecoenv.2016.03.012.

Saxena, P., Kulshrestha, U. 2016. Biochemical effects of air pollutants on plants. - Kulshrestha, U., Saxena, P. (eds.). Plant Responses to Air Pollution. Singapore, Springer, 59-70. https:/ / doi.org/10.1007/978-981-10-1201-3_6.

Smailagić, A., Ristivojević, P., Dimkić, I., Pavlović, T., Zagorac, D.D., Veljović, S., Akšić, M.F., Meland, M., Natić, M. 2020. Radical scavenging and antimicrobial properties of polyphenol rich waste wood extracts. - Foods, 9(3), 319. https:/ / doi.org/10.3390/foods9030319.

Şöhretoğlu, D., Ekizoğlu, M., Kiliç, E., Sakar, M.K. 2007. Antibacterial and antifungal activities of some Quercus species growing in Turkey. - FABAD Journal of Pharmaceutical Sciences, 32(3), 127-130.

Stafasani, M., Devolli, A., Feta, D., Shahinasi, E. 2018. The solubility of Turkey oak (Quercus cerris L.) wood in water. - Albanian Journal of Agricultural Sciences, 634-640.

Stafasani, M., Toromani, E. 2015. Growthclimate response of young Turkey oak (Quercus cerris L.) coppice forest stands along longitudinal gradient in Albania. - South-east European forestry, 6(1), 25-38. http://dx.doi. org/10.15177/seefor.15-05.

Taib, M., Rezzak, Y., Bouyazza, L., Lyoussi, B. 2020. Medicinal uses, phytochemistry, and pharmacological activities of Quercus species. - Evidence-Based Complementary and Alternative Medicine, 2020, 1-20. https:/ / doi. org/10.1155/2020/1920683.

Tantray, Y.R., Wani, M.S., Hussain, A. 2017. Genus Quercus: An overview. - International Journal of Advance Research in Science and Engineering, 6(8), 1880-1886. 
Tzvetkova, N., Kolarov, D. 1996. Effect of air pollution on carbohydrate and nutrients concentrations in some deciduous tree species. - Bulgarian Journal of Plant Physiology, 22(12), 53-63.

Vannini, A., Valentini, R., Luisi, N. 1996. Impact of drought and Hypoxylon mediterraneum on oak decline in the Mediterranean region. - Annals of Forest Science, 53(2-3), 753-760. https:// doi.org/10.1051/forest:19960251.

Vinha, A.F., Barreira, J.C.M., Costa, A.S.G., Oliveira, M.B.P.P. 2016. A new age for Quercus spp. fruits: Review on nutritional and phytochemical composition and related biological activities of acorns. - Comprehensive Reviews in Food Science and Food Safety, 15(6), 947-981. https://doi.org/10.1111/15414337.12220.
Weidlich, W.H. 1978. A preliminary report on a method of biological control of the chestnut blight not involving the use of a hypovirulent strain of Endothia parasitica. - Proceedings of the American Chestnut Symposium, USA, Jan. 1978. Morgantown, West Virginia, 79-83.

Wilson, A.D. 2005. Recent advances in the control of oak wilt in the United States. - Plant Pathology Journal, 4(2), 177-191. https:// dx.doi.org/10.3923/ppj.2005.177.191. 